\title{
Malignant Soft Tissue Neoplasm
}

National Cancer Institute

\section{Source}

National Cancer Institute. Malignant Soft Tissue Neoplasm. NCI Thesaurus. Code C4867.

A malignant neoplasm arising exclusively from the soft tissues. 